\title{
Sensing History. \\ On the Uses of Medium-Specific Noise in Eastern European Found Footage Films
}

\author{
Melinda Blos-Jáni \\ Sapientia Hungarian University of Transylvania (Cluj-Napoca, Romania) \\ E-mail: blosmelinda@kv.sapientia.ro
}

\begin{abstract}
This article examines how sensual aspects of the moving image, such as visual errors, blurring and technical disturbances are employed in found footage films dealing with Eastern European socialist past and the regime changing events. In the selected films Eastern European socialist visual culture is reworked with the cinematic practices of the post-media age in order to shape the spectators' historical consciousness. By deliberate reframing and intensifying the medium-specific noises of the archival sources, or by an artificially created visual precariousness a new type of spectatorial awareness is created. The article delineates four different strategies through which the mediality of the recycled archival footage is brought to the fore and made operational (engaging the senses of its viewers). ${ }^{1}$
\end{abstract}

Keywords: found footage film, socialist past, medium-specific noise, haptic visuality, intermediality.

History has become "something to be shown before narrated" (Ruchel-Stockmans 2015, 41).

The recent boom of reassemblage-filmmaking has turned found footage films into a lively field of research as it aroused the interest of scholars dealing with representation of history and memory, documentary cinema, and media archaeology. Questions regarding contemporary image recycling exceed the classical theoretical frames provided by such authors as Jay Leyda (1964), William Wees (1992), Catherine Russel (1999) or Paul Arthur (1999). These texts proved to be paradigmatic in defining found footage filmmaking, yet the variety of historical events and of the aesthetical approaches to the past (a wide array

1 This work was supported by a grant of the Ministry of National Education, CNCS - UEFISCDI Romania, project number PN-III-P4-ID-PCE-2016-0418. 
of conventional and experimental techniques) raise new questions about the performativity of archival images.

This article explores reassemblage works that offer innovative ways of representing Eastern European history through a media conscious reworking of archival materials. The socialist history of Eastern European countries has been processed and polemically addressed by several filmmakers as a kind of plea for a collective memory work. These works ponder on the regime changing events but also on the everyday life under socialism, through ingenious reshaping of the images of communism. The fall of the Iron Curtain has been interpreted as a media event in itself, ${ }^{2}$ a highly staged spectacle, effectively dissected in Videograms of a Revolution (Videogramme einer Revolution, 1992, Harun Farocki-Andrei Ujică), an event which, paradoxically, is part of a vivid, communicative memory - in the sense Jan Assmann (2011) uses the term -, at least part of the memory of the generations born before the 1980s. One of the characteristics of the films dealing with the socialist past is that they initiate their spectator into a memory work that is different from artworks dealing with post-memory (e.g. with the topic of World War II). The materials available for recycling are also idiosyncratic to the socialist years, thus an Eastern European found footage filmmaker works either with the official televisual and propaganda records (mostly $16 \mathrm{~mm}$ film), pirated materials originating from the black market, or with amateur media (home video). These differences are creatively reused in the cinematic medium chosen by the filmmaker, who adapts or conflicts medial differences, just as Farocki and Ujică do in Videograms when they juxtapose the professional, state-controlled media with the rise of the independent gaze of video cameras.

Images of communism are either propaganda inflected (such as educational documentaries, newsreels, television broadcasts) or restricted to a very personal point of view (amateur materials). The control society turned photo-based visual culture either into a vehicle of agitation, or downplayed the documentary potential of the photographic images, by promoting it as a highly artificial artistry and delegating it into the realm of crafts (Bădică 2014, 209). In spite of a multitude of visual documents made before 1989, there is a lack of images depicting the actual socialist reality (Bădică 2014, 215). Although there are images to see, these do not really relate to the lived experiences that people remember. Thus, the existing archival materials are considered unreliable witnesses of their times, which stimulate contemporary filmmakers to perform a kind of skeptical distancing

2 Vilém Flusser famously declared that in the case of the Romanian revolution "there is no reality behind the image, there are realities in the image" (1990). 
from the visibility these images of past afford. As these films suspend the representational conventions (e.g. the indexicality of film), a figurative reshaping occurs, which Paul Arthur defines as metaphoric fabrications of reality $(1999,66)$.

Although editing and juxtaposition of sound and image are traditionally considered to be the main re-interpretive tools in found footage cinema (Arthur 2000, 63), recent Eastern European productions seem to move beyond the assemblage of fragments, and attempt to interrogate or detour the images inherited from the socialist period through an aesthetic based on technical errors and blurred vision. While constructivist theories such as the montage of attractions or Vertov's interval investigated the ways in which pieces can be put together in order to produce new meaning, in recent examples one can find an unprecedented fascination with the medium and the materiality of the image. Meta-mediumistic, materialist strategies prevail in the cinema of the digital age. The increasingly sharper, high definition image and the immersivity of 3D technologies has resulted in a hyper-realist aesthetic, but also in a revival of the decorative, pretty image (Galt 2011) or the tableau aesthetic (Pethő 2014), but contemporary cinema also developed the opposing strategy of "poor images" (Steyerl 2009), low definition (Casetti-Somaini 2013, Balsom 2017), vague/ indefinite (Beugnet 2017), non-cinematic (Nagib 2016, Brown 2016) or the socalled precarious aesthetic (Fetveit 2015). Arild Fetveit identified the cinematic retooling of originally unwanted "symptoms of wear and tear, malfunctions characteristic of specific media as deliberate expressive devices" $(2013,189)$ as a new aesthetics: that of the medium-specific noise. Deliberate use of visual errors might signal an opposition towards mainstream media aesthetics and representations, and function as "a potential point of resistance" against the culture of photographic transparency (Beugnet 2017, 10), or noises can testify to the embodied dimensions of images, as a reflection on how representations become and connect us to the world (Fetveit 2013, 197).

The motivations for "thickening" the medium and blurring of vision in a found footage film is different in a more classical, narrative documentary form, where archival images function as markers of authenticity rather than as the primary source for the documentarist project (Arthur 1999, 61). Subverting the denotative and indexical integrity of archival images was more characteristic to avantgarde practices, where refiguration and creative unmasking of the materiality of the image became the norm. Unmediated transparency and exact evidential illustration is the exception rather than the rule within both paradigms (Arthur $1999,66)$. Signs of visual precarity or deterioration play a decisive role in the 
figurative reshaping of the archival image: within the documentary paradigm they become figures of authenticity and truth, while in avant-garde projects they tend to figurate mediation itself.

In contemporary practices the differences between documentarist and experimental reassemblage have blurred simultaneously with the changing significance of low-definition images in the new media environment. Questions of mediation haunt even the most traditional, narrative documentaries, too. According to Erika Balsom, in the context of the new media hybridisation, "lowdefinition images shift from the markers of specificity they were in the 1920s to markers of intermediality and cinematic expansion" $(2017,84)$.

In found footage films, medium-specific noise becomes a figuration of intermediality, and it is also bound up with questions relating to embodied vision. Emphasizing the tactile qualities of film brings into mind Laura Marks's notion, the skin of the film (2000), but also Hans Belting's definition of the medium as a body where images are performed (2014). Certain uses of archival images seem to be paradigmatic examples for history unfolded through haptic visuality, which according to Marks, "values the material labor of embodied reception as a way of being open to the unknown without seeking to master it" (2017, 30-31). Moreover, when mobilized through haptic tactics, archival images become "lures to feeling and thought" (Whitehead paraphrased by Marks 2015, 173). But the intensification of perception and consciousness also alters the possibilities of knowing history through images. When a found footage practice calls for embodied vision, it also redefines documentary from a mode of making visible into a mode of alluding to the edge of vision and to the lack of things to see, creating a case of paradox visibility (see Tarnay 2017). In Aleida Assmann's words: "material traces are signs which can restore only 'a miserable defective shred' of the magic web of the past" $(1996,132)$. The laconic character of the images, their blacks (in the sense DidiHuberman uses the term, 2008) and blurs create a distance from what seems to be an instant view of reality, but they also make an impact on the real, affecting the here and now of the spectator.

The following subchapters look at Eastern European found footage films to investigate how the medium of film becomes the skin of the past (instead of an image of it) through different media strategies in order to provoke historical consciousness in the spectator. By delineating four, at times simultaneously present strategies of this media aesthetics, the article will demonstrate how socialist past is enfolded and unfolded from visual sources held to be unreliable and with a deficiency in realism. 


\section{The Sensual Archaeology of the Archive}

"Mining of the mnemonic depths of the archives," according to Patricia Pisters (2016, 162), is besides the multiplications of perspectives on the past and an intensive affecting remixing, one of the "metallurgic" principles employed by filmmakers trying to find the singular and the contingent in an abundance of archives, in order to enable a fresh look at history. The processes of detecting and digging up materials affect the value of images, and also the creative practice and the aesthetics of the artistic product.

The sheer multitude to plough through transforms every bit of finding into an enigmatic fossil rather than a meaningful whole. Aleida Assmann suggests that as more and more data are registered, and archives are established, cultural memory is redefined: it becomes less reliant on texts, there is a shift from texts to traces and eventually to litter $(1996,132)$. Filmmakers reworking the archival documents of Eastern European past are in an idiosyncratic position as they have to excavate state archives which are not fully catalogued, nor digitized, moreover their collection is influenced by past ideologies or by a rough weeding-out of materials devaluated as the debris of a past regime. Working in closed, chaotic archives makes the smallest finding a treasure, no wonder the image of the archive resurfaces in so many Eastern European found footage films. [Figs. 1-2.] Sometimes raw materials are found outside the archives, which adheres them to a different kind of multitude, that of amateur media. On the other hand, during the excavation process, the filmmaker encounters different types of image materials or low quality transfers as research copies, which are in the end transferred digitally into pristine quality copies to be used in the film (to be remastered and assembled digitally) - all this renders the entangling of the material aspect of filmmaking an even more complicated puzzle.

Creating connections within the dilated, the expanded multitude or locating the most meaningful microfossil have turned found footage filmmaking into an archaeology, or a research-based artistic practice bordering on scientific ambition. Within this context, repurposing and assembling archival footage seems playful and serious at the same time: the creative outcome of this kind of filmmaking is almost always an epistemological treatise of the visual culture as well.

The films made by the Polish Maciej Drygas constitute an interesting example of this kind of filmmaking, as himself acknowledged that: "I don't really consider myself a filmmaker. I spend most of my time documenting history, and rarely make films. The job does in fact resemble the work of an archaeologist, to some 
extent. I reach under the surface, uncovering layer after layer, to find some bit of truth about the world I'm describing" (Czerkawski 2011). These films are not merely a product of an archival research, they are, at the same time, excavations into the way images work, gain depth and produce the "real." Moreover, the forementioned hands-on approach to research also influences the (media) aesthetics of the final artwork, in at least two ways.

\section{a) Manufacturing meaning within the multitude of images in the archive}

One of the most prevalent topic in the interviews on the pre-production processes of a reassemblage film is the amount of work that a filmmaker or its team dedicates to the selection of the visual material to be included in the film. The activity of "mining the depths of the archive" - which can be a physical pleasure, or an exhausting experience - puts the findings into an intermediary state of becoming, waiting to gain sufficient weight to enter the film. Some of Maciej Drygas's films: State of Weightlessness (Stan nieważkości, 1994), Voice of Hope (Głos nadziei, 2002), One Day in People's Poland (Jeden dzień w PRL, 2005), Violated Letters (Cudze listy, 2011) were made based on extensive research work with a duration of 3 to 5 years, based on the haptic encounter with the matters of the archives (with handwritten letters, film reels or sound tapes), as the director is famous for refusing to work with protective gloves. ${ }^{3}$ Even though these films do not really foreground haptic visuality, the physical contact during their elaboration had shaped significantly the historical awareness and empathy of the filmmaker.

There is also a longing of the archives to be dusted down and to be repurposed, most prominently expressed by such films that are commissioned by archives. For example, Deimantas Narkevicius's Into the Unknown (2009) was made on the invitation of the BFI and of Hartware MedienKunstVerein, Dortmund in order to mark the anniversary of the fall of the Iron Curtain with a film reusing material from the largest surviving collection of socialist propaganda films originating from the former GDR and housed by the BFI. As the title of the film suggests, the images originally designed to be reassuring and attractive at the same time are thrust into

3 "It's just about the everyday archaeological toil, digging pebbles out day after day after day. And I'm allergic to dust, so every year I need to go through a treatment to enable me to continue to work. I cry, I cough, but I just can't touch the archival material with gloves on. In the Polish Institute of Remembrance, there are tons and tons of files of the secret communist police, all the researchers work with masks and gloves on, but I just can't do it, because then I can't feel the material. I believe that if you want to find out the truth you need to pay the price, even if it's a physical price, crying and coughing. Touching the truth wearing a pair of white gloves just doesn't agree with my emotions.” (Drygas in Garrad 2012.) 
the unknown. Thus, images made to advertise the assembling line of a radio factory [Fig. 3], the design of the socialist home, or the operational health system is reframed through the soundtrack as uncanny and frail. Just as the church bells at the end of the film, which are shown in the process of being tuned and waiting to resonate [Fig. 4], the film makes the spectator feel for the images that are in an intermediary state, having lost their initial purpose and longing for new connections with the world.

Bringing new images to the surface through a haptic filmmaking practice does not necessarily lead to a materialist aesthetics, as there is a strong ambition to express new findings within the realm of the visible, and through it. In some cases, the process of archaeological exploration is often translated as a cinematic quest in the optical image, and as a result, the image is released from the grasp of an archive, from the material object it turns into a tool for making history visible. The physical experience of watching and re-watching raw images for months, and of locating the meaningful fossil exerts an impact on the cinematic reshaping of the materials, for example on the length of the shots or on editing.

There is a great expectation to discover the flux of history from the visible, by getting beyond what images represent and focusing on the ways they operate, in a Harun Farockian manner. The reality of the image is both asserted and reflected in this analytical mode. For example, in Videogramme einer Revolution (Harun Farocki-Andrei Ujică, 1992), shots taken from multiple points of view are put together chronologically so as to render possible the reconstruction of the Romanian events of December 1989, but this also draws attention to the ways images were produced in the television before and after the revolution, and to the perspective of video-amateurs. ${ }^{4}$ Similarly, in the Autobiography of Nicolae Ceauşescu (Autobiografia lui Nicolae Ceauşescu, Andrei Ujică, 2010) we can follow the life events of the former dictator, but also the ways in which he produced his own image (hence autobiography ${ }^{5}$ ) detectable in reel ends, registered by cameras before going into live transmission and while getting prepared before the public speeches and performances. ${ }^{6}$ The strong emphasis on

4 The filmmakers compiled their film from 120 hours of archival material collected from various sources (Ruchel-Stockmans 2015, 57).

5 The visual chronology of Ceauşescu's career is contextualized as his flow of memories that starts during the interrogation preceding his execution. Hence the word autobiography in the title. By defining it as memory, a certain autonomy is given to the image that weakens its potential of being an objective record of the past.

6 Reel ends are debris specific to the analogue media age. Dana Bunescu, the editor of the film even declared that the movie was possible because everything was recorded on celluloid film. See: Masterclass with Dana Bunescu, https://www.youtube.com/watch?v=rX9zplTH1Xw. /. Last accessed 25. 08. 2018. 
sequentiality, on the consecutive ordering of disparate materials in Videograms of a Revolution is also mentioned in an interview with Andrei Ujică: "the idea at the basis of the project can be summarized in this way: in 1989, a hundred cameras followed what was happening in Romania; history is no longer divided into theatrical scenes, nor into literary chapters - it is perceived as a sequence; and the sequence demands a film" (White 2011).

In the Autobiography of Nicolae Ceauşescu the filmmakers went even further, by giving a special role to the long sequence shot. Departing from the tiresome process of viewing a total of 260 hours long pre-selected footage, they decided to slow down the rhythm of the film starting from materials related to the 1980s, when a period of deprivation started. Thus, the final takes of the film are sustained with the intention of creating a sense of endless burden in the spectator (Dana Bunescu in Filippi and Rus 2011). The seemingly un-edited parts, like the sequence about Ceauşescu's visits to the shops have a non-cinematic character. ${ }^{7}$

Perhaps the most prevalent effect of an extensive analogue research and of digital post-production is a preference for seriality. As the editing emphasizes repetitions, the spectator gets a sense of quantity of the materials, or recognizes the database aesthetics of a digital storage system. The Autobiography of Nicolae Ceauşescu is a great example of cumulative editing: most memorable are the images of the heavily choreographed mass spectacles, or the series of images presenting the birthday flowers received by the dictator throughout the years.

Marta Popidova's Yugoslavia: How Ideology Moved Our Collective Body (Jugoslavija, kako je ideologija pokretala naše kolektivno telo, 2013) is a real feast in terms of cumulative editing. The filmmaker juxtaposes images covering mass gatherings in the Yugoslavian public space beginning from 1945 until 2000, from the installation of communism, through the creation of the youth movement's spectacular mass ornament-style stadium shows during the 1980s, up to Tito's funeral procession and the disintegration of the country. Yugoslavia, just as Videograms or the Autobiography became possible because of an "excessive representability of history" (Leslie 2004), ${ }^{8}$ but Popidova's film creates an even

7 See Nagib's analysis of the final long take from The Act of Killing (2016) building on Bazin's notion of realism.

8 The multitude of the images that allow this kind of archaeological filmmaking and the role of images in the course of history is mentioned in the voiceover of Videograms and also in an interview with Andrei Ujică: "since its invention, film has seemed destined to make history visible. It has been able to portray the past and to stage the present. We have seen Napoleon on horseback and Lenin on the train. Film was possible because there was history. Almost imperceptibly, like moving forward on a Möbius strip, the side was flipped. We look on and have to think: if film is possible then history too is possible" (White 2011). 
stronger bond between the multitude of images, the ideologies of collectivity, and the psychology of the masses. Departing from Kracauer's notion of the mass ornament, Popidova mobilizes a mass of images to uncover the moment when a sense of collectivity was exchanged for the sake of individualism that eventually led into chaos and destruction. Through a scrutiny intensified by the director's voiceover, the spectator is made to discover the moment of social change in the coordinated movement of the masses of dancers that shifts into the unruly movements of a dancing woman, who paradoxically, becomes the protagonist of the mass ornament show. [Figs. 5-8.] And this makes it probably the most enthusiastic Eastern European found footage film about what pictures can show. ${ }^{9}$

The manufactural, research based filmmaking shapes the aesthetics of these films, leaving its mark on the figurative dimension, but mostly on the editing of the film. The materialist aspects of filmmaking are enfolded in terms of music and rhythm (and not necessarily touch).

\section{b) Digging up the "radioactive fossil"}

There are images testifying to the shortcomings of official history or memory. These images embody traces of events without being able to represent it, but as "radioactive fossils" (Deleuze quoted by Marks 2000, 51) they can activate the process of memory. Such a fragment of only seven seconds constitutes the core of Drygas's first film, Hear My Cry (Usłyszcie mój krzyk!, 1991), which deals with Ryszard Siwiec's self-immolation as a protest on September 8, 1968 during a televised harvest festival at Warsaw Stadium. The story was very well hidden by officials and erased from the archives, although the spectacle of the harvest was a highly mediatized event. In spite of all, a small fragment of the TV recording survived, and the filmmaker found it in the Polish Archives as an object not listed in the official catalogue. The film makes dramaturgic use of the finding of the footage, as it withholds it until the final part of the film, embedding it into the narrative presentation of the main character and the act of immolation, through a series of talking head-style interviews made with family members and witnesses, and also within the story of the filmmaker's quest for visual documentation. Creating a certain kind of suspense, Drygas introduces the footage gradually, as short inserts that break the series of the interviews. Through ingenious reframing

9 This attitude towards visibility is manifested also through a written insert presenting a quote from Siegfried Kracauer: "spatial images [Raumbilder] are the dreams of society. Wherever the hieroglyphics of these images can be deciphered, one finds the basis of social reality." (The exact location of the quote is not specified in the film.) 
and slow motion, the emphasis shifts from the gestures of the dancers and the audience reacting to the human body in flames, then in the finale Siwiec's figure gets to be centrally framed and enlarged four times until there remains a freezed close up of a shouting man in flames. [Figs. 9-10.]

Prepared by the narrative context, and manipulated through medial interventions the seven seconds long fragment becomes a historical document, whose cultural, political and also material heritage is unearthed in this process. Firstly, through the recourse to repetition, delay and slowness the viewers are given a new chance to grasp the view and to get into a state of extended contemplation. As Laura Mulvey suggests, "extracting the image from a narrative surrounding gives the spectator the illusion of possession" $(2006,151)$. As Drygas' film artificially creates the sense of proximity to the image, if not to the burning, protesting man himself, the self-immolation becomes an image event and the spectator becomes another kind of participant. We do not get immersed in the event of the harvest festival, but we get to face a still image of a human self-sacrifice - the filmic image devoid of movement. The aesthetic of delay can also intensify the encounter with the index for "the fetishistic spectator, driven by the desire to stop, to hold and to repeat images [...]. The time of the camera, its embalmed time, comes to surface, shifting from the narrative now to the 'then.' Reality takes over the scene" (Mulvey 2006, 155).

The dissection of the footage into freeze frames continues with their enlargement until a grainy, highly textured, abstract image remains. While the director makes archaeological explorations in the depths of the image, sharpness and visibility disappears, and the physical holder of the image, as a haptic, almost tangible object appears, as if shielding it from further explorations. The indexical image presents a human body that is no longer identifiable, as if trapped in the televisual medium of the image. The archival properties of the image are reduced to a stain. No wonder, the fragment about the burning man has been compared to Malcolm Browne's shocking 1963 photograph about the self-immolating Saigon monk (Pfeifer 2018), and its inclusion in Ingmar Bergman's Persona (Coates 2015), as being an exploration about the limits of representation. Yet, regarding the sensing of history it is important to pinpoint the affinities of the title and the final image of the film with the Scream (1893) by Edward Munch. As the distorted landscape of the painting is connected to the sound waves emitted by the screaming figure, the unheard, forgotten cries of the burning man also penetrate the image of the film: as we get closer and closer to Ryszard Siwiec's face, the visual blur distorts the image as a visual equivalent of the unarticulated cry of a man protesting at the border of life and death. 
Cumulative editing and magnification of the fossil are the flip sides of the same coin: they are processes dedicated to rendering history visible either by mobilizing an army of images, or by enlarging the smallest fragments, even at the cost of exposing their material as being fragile and limited.

\section{Veiling the Image with Medium-Specific Noise}

This strategy usually means a simultaneous reliance on the image and its medium: it is important to create a domain of interest within the visible, but the affective power of a medium's materiality is also exploited. Veiling the image ${ }^{10}$ with analogue grain or electronic interferences in this case is not used as a materialist critique of the totalizing quest in the visible, or as a liberating counter-aesthetics with "poor images" (in the sense Hito Steyerl uses the term, 2009). In the following examples, medium-specific noise becomes primarily a means to add something to the image rather than an intervention to reduce or restrain its visibility.

Vladimir Tomić's Flotel Europa (2015) makes the most expansive use of this strategy when reusing footage originally recorded on analogue video. The film follows the fate of a refugee community who escaped from the horrors of the Yugoslavian war and found temporary shelter for two years on a floating ship in the harbours of Copenhagen. The story of the community is narrated by the voiceover of the director and it is visualized through digitized VHS-tapes made on the board of the so-called Flotel. Beside narrative cohesion, the voiceover impregnates the story with the idiosyncratically naive and playful point of view of a 12-year-old boy, who at the boundary of childhood and puberty does not have real concerns related to social history or nationhood. The footage was not edited in order to support the narrative in itself, nor to become an exact illustration of the voiceover, ${ }^{11}$ rather it becomes similar to a subjective memory flow. By emphasizing the flows of the electronic video signal, the viewer gets a chance to connect emphatically to Vladimir Tomić's stream of memories: "there were these moments where you sense that someone is struggling to get the tape to work, or a moment later in the film when a person watching the footage rewinds the tape. That was so much more useful than the material that was

10 The metaphors of veiling and rupture (see next chapter) are related here to the relationship between the image and its medial body, to a cinema of sensations, thus are not used in the sense George Didi-Huberman defines them. In his seminal book, Images in Spite of All (2008) veilimage and tear-image are analogous with Lacan's imaginary and the real $(2008,51-88)$.

11 The director himself declared this during a talk given after the screening of his film at CEU Budapest, at Screened Memories Summer University in 2016. 
cleanly digitised since it created yet more depth" - as Srđan Keča, the editor of the film has declared (Cohn 2015).

The unfolding of the past as a subjective memory through VHS images is prepared carefully in the first sequence of the film, with an abundance of medium-specific noises. [Figs. 11-12.] Errors like displaced colours or image interruptions characteristic to a demagnetizing VHS tape persists stubbornly during the segment of the video letter that the boy/director is producing together with his mother and older brother in front of the Flotel as a message to the father and other relatives who had chosen not to leave their home country. The video letter has a crucial role since finding it inspired the director to make the film, ${ }^{12}$ and it also functions as an establishing shot presenting the location and the main characters of the narrative. It is also important because it introduces the concept of the video as a veil that wraps the images with all the affective meaning that is attached to the medium of analogue home video as a dispositif, plus all the political and cultural implications that this technology - coming from the West could have in the socialist Eastern Europe.

The 1980s was the decade when video market expanded and even managed to gain access to the socialist everyday life, in spite of the state control over representational technologies. VHS tapes, video cameras and video players were a commodity desired by many and acquired by a few via smugglers, just as the storyline of the Romanian film Adalbert's Dream (Visul lui Adalbert, Gabriel Achim, 2012) demonstrates. ${ }^{13}$ Video had become not so much a narcissistic (see Krauss 1976), but rather a democratic medium in the Eastern Europe of the 1980s. ${ }^{14}$ In 1992, for the Bosnian family of Vladimir Tomić it was a means of communication with their home, in a period of unstable telephonic connections with Yugoslavia. Video can be seen as a medium enfolding the complex reality of the refugees from the Flotel. Television also appears in the film, but inversely, it is used to receive news from home, to unfold the world that they left behind. Images

12 After finding his own video letter, he collected video materials from his former Flotel-mates, and even managed to locate the producer of the VHS-tapes. The film was made from a total of 20-hour-long video footage (Cohn 2015).

13 The film presents the story of Adalbert, an amateur filmmaker and VHS-user in the socialist era, who while preparing a screening in his factory discovers, in an ironic way, how much reality differs from its filmic representation. Nevertheless, he manages to capitalize on his VHSrecorder by taping football games.

14 See, for example, the scholarly approach to the Polish phenomena, presented by Michał PabiśOrzeszyna in his talk entitled Video Connectors: Smuggling Westernity in Communist Poland (NECS Berlin, 2016). Based on recent in-depth research on VHS and video culture in Poland, he argues that the individualism embedded in the democratic media use has actually prepared the fall of communism. 
of refugees watching the news programme in the TV-room of the Flotel recur in the film, and supported by the voiceover these emanate a sense of belonging and home. Thus, television becomes an almost melodramatic medium.

After the introductory sequence of the noisy video letter, the veiling of the images continues through the occasional appearance of timestamps burnt on the image, and by the means of an electronic interference that lingers at the bottom of almost every image. The domain of the visible is constantly wrapped in mediumspecific noises, enveloping the life events of the inmates within the affectively and ideologically textured fabric of the video image.

Medium-specific noises are used to signal the presence of a medium within another (Fetveit 2013, 204) (as a kind of veiling) in many of the fore-mentioned films: textures, timestamps and video-specific low resolution is also present in Videograms of a Revolution and in Yugoslavia:How Ideology Moved Our Collective Body. Low resolution and VHS-specific errors in both examples drive attention to the presence of a camera, moreover the corporeality of the images is a means to confer presence to the subjectivity of the otherwise invisible filmmakers. Thus, the gesture of veiling seems to be attached to a form of expressing subjectivity, just as we have seen it in Flotel Europa. The veil equals here with a restriction of point of view, indicating that what we see is merely a fragment of a whole.

There are examples of remediation through medium-specific noise where the emotional wrap added to the image is nostalgia, indicated also by the term technostalgia (see van der Heijden 2015). This is the case of Gábor Zsigmond Papp's documentary series containing such titles as Budapest Retro 1-2 (2002, 2003), Balaton Retro (2007), Hungarian Retro 1-2 (2010, 2014). These documentaries are based on $16 \mathrm{~mm}$ celluloid-based newsreels that were usually projected in Hungarian cinemas before feature films. The veiling texture of the $16 \mathrm{~mm}$ celluloid can be seen as a way of distancing, as an ironic treatment of the often naive scenes in order to reveal their absurdity, but in the meantime it also induces a feeling of nostalgia through empathy towards the once palpable celluloid material. ${ }^{15}$

\section{Ruptures and Fissures on the Skin of the Past}

While the examples belonging to the veiling strategy demonstrated how noisy matter is used to wrap the visible and to generate emotional engagement, sometimes errors are used as ruptures, dissections on the film's body and are

15 Arild Fetveit argues that nostalgia articulated through noises "does not return us to a longed-for past, but sets up a relation to the past" $(2013,208)$. 
meant to generate embodied experiences related to a specific historical event. Within this strategy, various errors suddenly break the opacity of the medium (and all its cultural, political and aesthetic implications) in order to question the images' relationship to the real.

Videograms of a Revolution incited much theoretical interest for uncovering the ways images operate and for testing the Flusserian hypothesis on the role images play in historical events. ${ }^{16}$ Images, instead of representing the event with all its complexities, become the site of the event, or at least an "essential ingredient" in them (Ruchel-Stockmans 2015, 62). In Videograms there are at least two gestures in which medium plays a crucial role among the attempts "to create a space for critique from within the images" (Ruchel-Stockmans 2015, 62). First of all, a sense of rupture and discontinuity is caused by the juxtaposition of multiple types of images as a continuous time flow: the film structures the events of the 1989 Romanian revolution as a colossal 3D puzzle, as it combines different viewpoints of the same event. There is a multiplication of fields of vision, marked by different mediatic veils, like those of the live TV broadcasts and amateur video. Through editing they become oppositional: TV as the medium and the institution of the control society and amateur video as the inarticulate, a medium of the private sphere. By juxtaposing them, their discrepancies come to the fore, and - as video renders visible what TV images conceal - they become ideal to supplement each other during the expansive investigation of the event (Ruchel-Stockmans 2015, 72).

However, the most significant visual error embedded in the film is the technical disturbance that interrupts the live broadcast of Nicolae Ceauşescu's last public speech. [Figs. 13-14.] The dictator's carefully planned speech and his attempt to reaffirm his position of power fails when the mass gathering transforms into a fervent protest. TV images try to conceal the disobedient crowd by turning the camera away from the turmoil, yet a sudden interference in the signal renders the image unstable and eventually interrupts the live broadcast. Thus precariousness and error tears the pre-fabricated aesthetics of the control society, moreover image disturbance becomes the event of the revolution, the very moment of the falling apart of a totalizing system. [Figs. 15-16.] The moment of rupture is enhanced with the subtitling of the broadcasting team's barely audible discussion trying to explain the error, one of them even utters: "earthquake."

Theorists of the 1990s conceptualized the televised revolution in Romania as the "end of history," as being l'art pour l'art (Flusser 1990), a reality of the image

16 For a detailed overview of the filmmaking process and an in-depth analysis of the film see Ruchel-Stockmans 2015, 55-97. 
or an example of simulacra and dissolution of history (Baudrillard 1994, 54). But recently emerged concepts, such as non-cinema (Nagib 2016; Brown 2016), allow it to understand these ruptures as "going underneath the surface," as part of a counter-aesthetics based on errors precisely to occupy an oppositional stance towards an established image regime (itself derived from a real social regime) and to reconnect the precarious images with a reality in transition. The aesthetics of non-cinema, in a post-indexical manner, considers the artifice of cinema as a passage to the material reality via medial transmissions and variations (see the interview with Lucia Nagib in the present issue of the journal).

Andrei Ujică, as the director of The Autobiography of Nicolae Ceauşescu (the follow up of Videograms) has declared: "if you are attentive and look hard enough - and this is why the film must be this long - you discover that no propaganda in the world can manage to make a complete mise en scène out of reality. Behind or on the sides of the images you discover fragments of true life" (Peranson 2010, 67). He calls it infra-level (as opposed to meta-level) realism to use nonfictional raw material, as one of his main preoccupations is the primary discourse of a film (instead of a secondary discourse of the found footage director). Andrei Ujică capitalizes on the excesses and margins of representation and lets images speak for themselves ${ }^{17}$ in The Autobiography of Nicolae Ceauşescu, and his commentary upon the images is expressed mostly through an intricate combination of naturalistic and abstract sounds.

Looking behind images, peeping through the tectonic lines becomes important within this infra-vision at a key point of the film. At the beginning of the third hour of the film, there is a cut to a black screen over which screaming and commotion can be heard. This sound fragment is a historical document, as the director explains: "on the evening of March 4, 1977, at 9.22 p.m., a 7.3-magnitude earthquake hit Romania, destroying a vast part of Bucharest and having an impact on the entire southern area of the country. At that very time, the Radio Hall was hosting a symphonic concert. The earthquake took place during the break, but a magnetophone was on in the recording cabin, to 'catch the background,' as they say. It recorded a little over twenty seconds of earthquake noise, half of the total duration. We wanted to give this acoustic document a context fitting its gravity, that's why we put it on black" (White 2011).

Thus, real noises become like a black screen that ruptures the fabric of The Autobiography of Nicolae Ceauşescu; for a few moments unruly sounds suggest

17 Harun Farocki had a similar definition of his work with images: "my way is to look for submerged meaning, clearing away the detritus on the images" (Foster 2004, 158). 
a world missing from the official pantomime. Sound turns off the image, just like the revolution as disturbance had done it in the previous film. By taking up the metaphor of earthquake from Videograms, a rupture of the image is produced to designate a real earthquake. Reaching the infra-level means getting under the skin of the film, which combined with the archaeological approach to images (the search for meaningful micro-moments) constitutes strategies to re-assert the historical truth.

Marta Popidova in Yugoslavia also uses the electronic disturbances of the videos made during the events marking the disintegration of the confederation. In her film errors of the image signal the transformation of the unified collective into a gang that does not restrain itself from pointless vandalism. Just as an individualist crowd emerges, and people enthusiastically engage themselves in the destruction of the remnants of the former Yugoslavia, the image becomes more imperfect. Visibility is reduced by profilmic blurring effects, like images of smoke on the streets, but also by the grainy texture and the hesitant use of the medium of video. [Figs. 17-18.] Thus, just as we have seen it in Videograms and in The Autobiography, medium-specific noises can break the illusion of a (visual) regime in order to indicate the beginning of a state of transition. The technical disturbance in Videograms, just like a Barthesian punctum, signals the beginning of an intermediary state of an unruly image operation that will last until the establishment of a new televisual image regime. In The Autobiography the earthquake of the image also signals the start of a harsher period in the life of the dictator and of the country that eventually led to the much darker period of the 1980s' Romanian communism.

\section{The Iconoclasm of the Interval}

In the films that create a sense of rupture via tactility, medial imperfections do not mean an effacing of the visible, much rather they indicate the moment when a change occurs within the regimes of the visible. On the other hand, the strategy of iconoclasm is about letting astray all the indexical expectations from images' visibility and releasing the image as pure sensation. It is like moving within the gap between the image and its medium in order mobilize the viewer into an active participant in finding meaning.

The key example of this strategy is The Second Game (Al doilea joc, 2014), directed by Corneliu Porumboiu, a Romanian New Wave director known for his variations on conceptual realism (State 2015). His move into experimental 
nonfiction designates in fact a fiction filmmaker's quest for the real within the non-cinematic, or on the "margins of cinema," as one of his critics disapprovingly remarked (State 2015, 87). Porumboiu declared that he had chosen to recycle this specific football game because he remembered it as the worst image he had ever seen on television. ${ }^{18}$ The film consists in the remediation of a VHS recording of a football game's live broadcast from December 3, 1988, played by the two main Romanian teams, Steaua and Dinamo. The football event has an autobiographical character as well, as the director remembers watching it live on television, and furthermore, his father, Adrian Porumboiu was the referee of the game. Shortly after the game started, a heavy snowfall began that made the profilmic reality barely discernible. The blurriness caused by the snow is doubled by the medial noises of the televisual broadcast and the grainy texture of the VHS recording. On the soundtrack we can hear the discussion of the filmmaker with his father as they rewatch the game, just like a home video, 25 years later. Their discussion tackles questions of ethics and aesthetics, such as the rules of the game, sport etiquette during socialism, or the visual style of the live broadcast, in which the director even recognizes a similarity with his own preference for long sequences. The voiceover commentary introduces questions related to memory, inheritance and the representation of history to the issues of intermediality and visibility implied by the images. It is precisely due to these questions that Patricia Pfeifer has chosen the term interval to describe the film, which she also sees "as a mediabased interstice and as an aesthetic-epistemological approach to a retrospective understanding of history" $(2017,238)$. The term is borrowed from the title of an exhibition, The Seductiveness of the Interval, opened at the Romanian pavilion at the Venice Biennale in 2014, where Porumboiu's film was commissioned to be part of an architectural site-specific installation representing the interval. Within the rich discussion about the uses of the in-between in Porumboiu's film, the author uses the words break and interruption as synonyms of the interval (Pfeifer 2017, 235), moreover she compares it with the technical interference that occurred during Ceauşescu's last speech (Pfeifer 2017, 239). However, it is also important to stress the differences between interval and interruption. While the strategy of rupture is actually a dramaturgic one, disturbance marks the moment of transformation visually (and in the case of Videograms we also see what precedes it, and its outcome too); in The Second Game the interval could be perceived as an opening, or as a temporal frame, yet unshaped and uncanny, longing for the spectators' willingness to unfold it and connect to it by activating their own 
historical consciousness. Instead of emphasizing the break, I propose to think of it as flow, where the phenomenology of the passage is more important than the state of before and after. The Second Game is about this intermediary state of transition, the in-between of television, VHS and the cinematic screen, but also about the in-between of a socialist past and the present. In order to sustain and to expand the interval, the director restrains himself from editing and embraces the unruly, noisy in the image as a kind of iconoclasm. ${ }^{19}$ The game is scarcely visible, there are difficulties in locating the ball in the image, and all the players are effaced. [Figs. 19-20.] In terms of media aesthetics, The Second Game renders its own corporeality visible on the detriment of images of corporeality. By showing the textures and incongruities of the skin of the film, this strategy capitalizes on haptic vision, on pure sensation that according to László Tarnay can relate us to our mental images, to the non-thinkable $(2017,24)$. Thus, the iconoclasm of the interval is meant to set our consciousness free from any kind of images that shaped our imagination in the past, or in the present. The reliance on the sensible materiality and on indefinite vision provokes desire in the viewer towards the unmediated, "the object perceptively 'lacking' in the image" (Tarnay 2017, 26).

Fetveit also understands the ubiquitous uses of medium-specific noise as a form of iconoclasm, that according to Groys can be defined as a rivalry between media, "as a sign of progress, where it appears to clear our path of all that has become redundant, powerless and void of inner meaning" (Groys quoted by Fetveit 2013, 205). From this perspective, the iconoclasm of the interval in The Second Game can be seen as a retooling of what was formerly unwanted noise (at least this is how Porumboiu's father sees the images) into an artistic device that allows "to approach that which cannot be integrated into the narrative of historical continuity” (Pfeifer 2017, 248).

\section{Conclusion}

These found footage films show us images that do not represent reality, but rather trigger our imaginary. They seem to challenge the concept of the frame as a container of images, or the frame as the boundary of a meaningful whole, instead they feature the image as a surface, or in Laura Marks's terms, a haptic visuality: "it is most valuable to think of the skin of the film not as a screen

19 Black frames in-between the flow of images occasionally appear in The Autobiography of Nicolae Ceauşescu as well, but they are intended as a respite between main chapters, rather than iconoclastic. (See the interview with Bunescu, Filippi and Rus 2011.) 
but as a membrane that brings its audience into contact with material form of memory" (Marks 2000, 243). In these films the aesthetics of medium-specific noises afford sensable versions of history. Doing history through this type of films means being open to reverberate with new sensations and to rework our own memories. Communicative memory, as a type of historical consciousness that is not yet solidified, seems to go hand in hand with indefinite vision in these Eastern European films.

Sensual archaeology, veiling, rupture and iconoclasm are strategies that resort to errors, repetition and excess, and to different degrees reject the pre-constitution of meanings, the comforts of visibility in order to lure the viewers into their own quest for hidden meanings and memories. These strategies afford the viewer their own "noisy brush with the infinite" (Marks, 2013). Visual contingencies do not achieve the effect of immediacy, they do not figurate the real, they appear instead as hypermediated, as constraints of the real or even of iconic figuration, and they bring us back to the litter (Assmann 1996) or to the stain, the sheer marker of existence (Doane 2007). Images become noise, rhythm and music. They are sounding history (just as tapping on the membrane of a drum) through medium-specific noise.

\section{References}

Arthur, Paul. 2000. The Status of Found Footage. Spectator. The University of Southern California Journal of Film and Television vol. 20, no. 1: 57-69.

Assmann, Aleida. 1996. Texts, Traces, Trash: The Changing Media of Cultural Memory. Representations no. 56: 123-134.

Assmann, Jan. 2011. Cultural Memory and Early Civilization. Writing, Remembrance, and Political Imagination. Cambridge UK [etc.]: Cambridge University Press.

Balsom, Erika. 2017. One Hundred Years of Low Definition. In Indefinite Visions:

Cinema and the Attractions of Uncertainty, eds. Martine Beugnet, Allan Cameron and Arild Fetveit, 73-89. Edinburgh: Edinburgh University Press.

Baudrillard, Jean. 1994. The Illusion of the End. Stanford: Stanford University Press.

Bădică, Simina. 2014. “Forbidden Images?” Visual Memories of Romanian Communism before and after 1989. In Remembering Communism: Private and Public Recollections of Lived Experience in Southeast Europe, eds. Maria Todorova, Augusta Dimou and Stefan Troebst, 201-216. Budapest: Central European University Press. 
Belting, Hans. 2005. Image, Medium, Body. A New Approach to Iconology. Critical Inquiry vol. 31, no. 2: 302-319.

Beugnet, Martine. 2017. Introduction. In Indefinite Visions: Cinema and the Attractions of Uncertainty, eds. Martine Beugnet, Allan Cameron and Arild Fetveit, 1-13. Edinburgh: Edinburgh University Press.

Brown, William. 2016. Non-Cinema: Digital, Ethics, Multitude. Film Philosophy vol. 20, no. 1: 104-130.

Casetti, Francesco and Antonio Somaini. 2013. The Conflict between High Definition and Low Definition in Contemporary Cinema. Convergence: The International Journal of Research into New Media Technologies vol. 19, no. 4: 415-422.

Coates, Paul. 2015. Varieties of Smallness: A Swedish Art Film (Persona), a Polish Documentary (Hear My Cry). In European Visions: Small Cinemas in Transition, eds. Janelle Blankenship and Tobias Nagl, 129-140. Bielefeld: Transcript.

Cohn, Pamela. 2015. Videos Home: How VHS Found Footage Became a Groundbreaking Film about Bosnian Refugees. The Calvert Journal. https:// www.calvertjournal.com/articles/show/4521/flotel-europa-vladimir-tomicsrdan-keca. Last accessed 25. 08. 2018.

Czerkawski, Piotr. 2011. Filmmaker and Archaeologist. Talk with Maciej Drygas. Biweekly.pl. https://www.biweekly.pl/article/2307-filmmaker-andarchaeologist.html. Last accessed 25. 08. 2018.

Didi-Huberman, Georges. 2008. Images in Spite of All. Four Photographs from Auschwitz. Chicago: University of Chicago Press.

Doane, Mary Ann. 2007. The Indexical and the Concept of Medium Specificity. differences vol. 18, no. 1: 128-152.

Fetveit, Arild. 2013. Medium-Specific Noise. In Thinking Media Aesthetics. Media Studies, Film Studies and the Arts, ed. Liv Hausken, 189-215. Frankfurt am Main: Peter Lang.

Fetveit, Arild. 2015. Death, Beauty, and Iconoclastic Nostalgia: Precarious Aesthetics and Lana Del Rey. NECSUS (Autumn). https://necsus-ejms.org/ death-beauty-and-iconoclastic-nostalgia-precarious-aesthetics-and-lana-delrey/. Last accessed 25. 08. 2018.

Filippi, Gabriela and Andrei Rus. 2011. În dialog cu Dana Bunescu. Film Menu vol. 10: 30-41. https://filmmenu.wordpress.com/2014/11/10/interviu-danabunescu/. Last accessed 25. 08. 2018. 
Foster, Hal. 2004. Vision Quest. The Cinema of Harun Farocki. Artforum: 156161.

Flusser, Vilém. 1990. Television Image and Political Space in the Light of the Romanian Revolution. Lecture delivered on 7 April in Kunsthalle, Budapest. https://www.youtube.com/watch?v=QFTaY2u4NvI\&feature=channel_video_ title. Last accessed at 25. 08. 2018.

Galt, Rosalind. 2011. Pretty. Film and the Decorative Image. New York: Columbia University Press.

Garrad, Michael. 2012. State of Weightlessness. Vertigo Magazine no. 31. https:// www.closeupfilmcentre.com/vertigo_magazine/issue-31-winter-2012-inconversation/state-of-weightlessness/. Last accessed 25. 08. 2018.

van der Heijden, Tim. 2015. Technostalgia of the Present: From Technologies of Memory to a Memory of Technologies. NECSUS (Autumn). https://necsusejms.org/technostalgia-present-technologies-memory-memory-technologies/. Last accessed at 25. 08. 2018.

Leslie, Esther. 2004. Documents of Revolution. Incompetence and Resistance. Film International vol. 2, no. 4: 26-37.

Leyda, Jay. 1964. Films Beget Films. A Study of the Compilation Film. New York: Hill and Wang.

Marks, Laura U. 2000. The Skin of the Film. Intercultural Cinema, Embodiment, and the Senses. Durham and London: Duke University Press.

Marks, Laura U. 2013. A Noisy Brush with the Infinite. Noise in EnfoldingUnfolding Aesthetics. In The Oxford Handbook of Sound and Image in Digital Media, eds. Carol Vernallis, Amy Herzog and John Richardson, 101-114. New York: Oxford University Press.

Marks, Laura U. 2015. Hanan Al-Cinema. Affections for the Moving Image. Cambridge, MA: MIT Press.

Marks, Laura U. 2017. Archival Romances: Found, Compressed and Loved Again. FKW // Zeitschrift für Geschlechterforschung und Visuelle Kultur no. 61: 30-41.

Mulvey, Laura. 2006. The Possessive Spectator. In Stillness and Time:Photography and the Moving Image, eds. Joanna Lowry and David Green, 151-163. Brighton: Photoworks.

Nagib, Lúcia. 2016. Non-Cinema, or the Location of Politics in Film. FilmPhilosophy vol. 20, no. 1: 131-148. https://www.euppublishing.com/doi/ full/10.3366/film.2016.0007. Last accessed 25. 08. 2018. 
Peranson, Mark. 2010. The Greatest Dictator. The Autobiography of Nicolae Ceauşescu (by Andrei Ujică). Cinema Scope no. 43: 63-68.

Pethô, Ágnes. 2014. The Tableau Vivant as a "Figure of Return” in Contemporary East European Cinema. Acta Universitatis Sapientiae: Film and Media Studies vol. 9: 51-77. http://www.acta.sapientia.ro/acta-film/C9/film9-3.pdf. Last accessed 25. 08. 2018.

Pfeifer, Moritz. 2018. The Double Death of Ryszard Siwiec. Maciej Drygas' Hear My Cry (Usłyszcie mój krzyk!, 1991). East European Film Bulletin vol. 84. https://eefb.org/retrospectives/maciej-drygas-hear-my-cry-uslyszcie-mojkrzyk-1991/. Last accessed 25. 08. 2018.

Pfeifer, Patricia. 2017. The Spectator in the Interval: Corneliu Porumboiu's The Second Game (2014) and Marta Popivoda's Mass Ornament \#1 (2013). Studies in Eastern European Cinema vol. 8, no. 3: 232-251.

Pisters, Patricia. 2016. The Filmmaker as Metallurgist: Political Cinema and World Memory. Film-Philosophy vol. 20, no. 1: 149-167. https://www.euppublishing. com/doi/full/10.3366/film.2016.0008. Last accessed 25. 08. 2018.

Ruchel-Stockmans, Katarzyna. 2015. Images Performing History: Photography and Representations of the Past in European Art after 1989. Leuven: Leuven University Press.

State, Andrei. 2014. Realismele lui Corneliu Porumboiu [The Realisms of Corneliu Porumboiu]. In Politicile filmului. Contribuții la interpretarea cinemaului românesc contemporan [The Politics of Film. Contributions to the Interpretation of Contemporary Romanian Cinema], eds. Andrei Gorzo and Andrei State, 73-89. Cluj-Napoca: Tact.

Steyerl, Hito. 2009. In Defense of the Poor Image. E-flux no. 10. https://www.eflux.com/journal/10/61362/in-defense-of-the-poor-image/73. Last accessed 25. 08. 2018.

Tarnay, László. 2017. Paradoxes of Visibility. Acta Universitatis Sapientiae: Film and Media Studies vol. 14: 7-30. http://www.acta.sapientia.ro/acta-film/C14/ film14-01.pdf. Last accessed 25. 08. 2018.

Wees, William C. 1993. Recycled Images: The Art and Politics of Found Footage Films. New York: Anthology Film Archives.

White, Rob. 2011. Interview with Andrei Ujică. Film Quarterly vol. 64, no. 3. https://filmquarterly.org/2011/03/09/interview-with-andrei-ujica/. Last accessed 25. 08. 2018. 


\section{List of Figures}

Figures 1-2. In Maciej Drygas's Hear My Cry a long sequence shows an archivist opening door after door, unlocking the depths of the archive that demands to be searched through with someone's hands. The image of a medical archive in Deimantas Narkevičius's Into the Unknown.
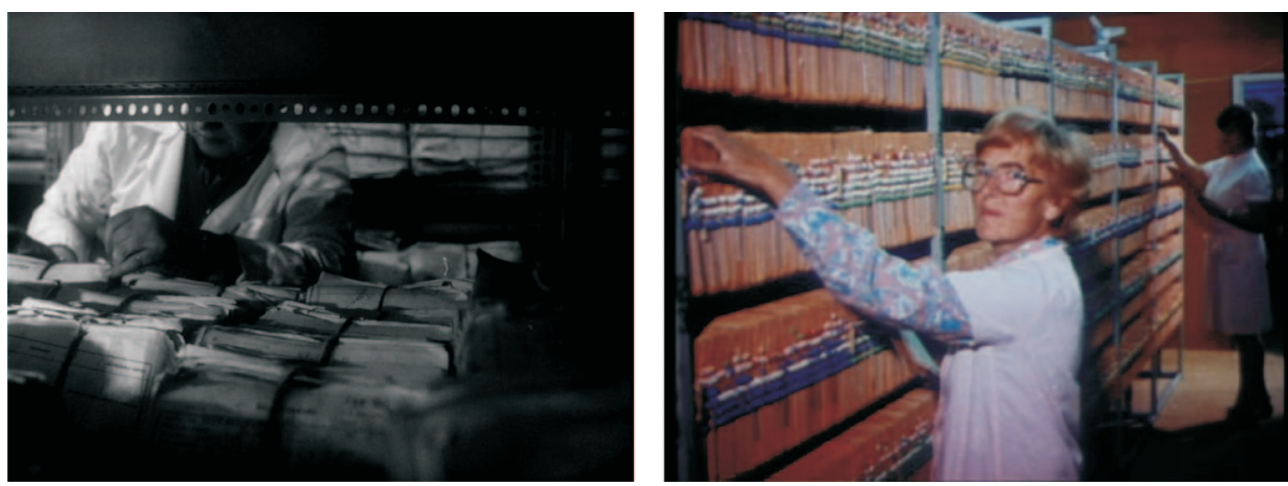

Figures 3-4. Two scenes, one about the radio-production line and the other about the tuning of the bells, put emphasis on a world of sounds.
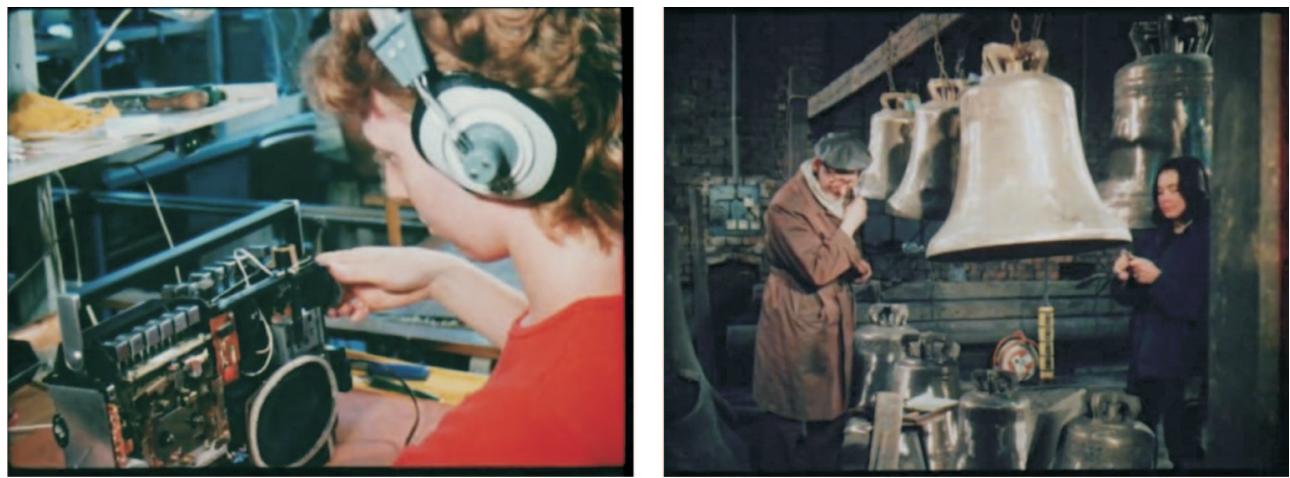
Figures 5-8. Scrutinizing the image of the crowd from the 1940's onward, until the stadium shows and colourful mass spectacles provide the first signs of a raising individualism (the body of a lone dancer standing out from the crowd) in Popidova’s Yugoslavia.
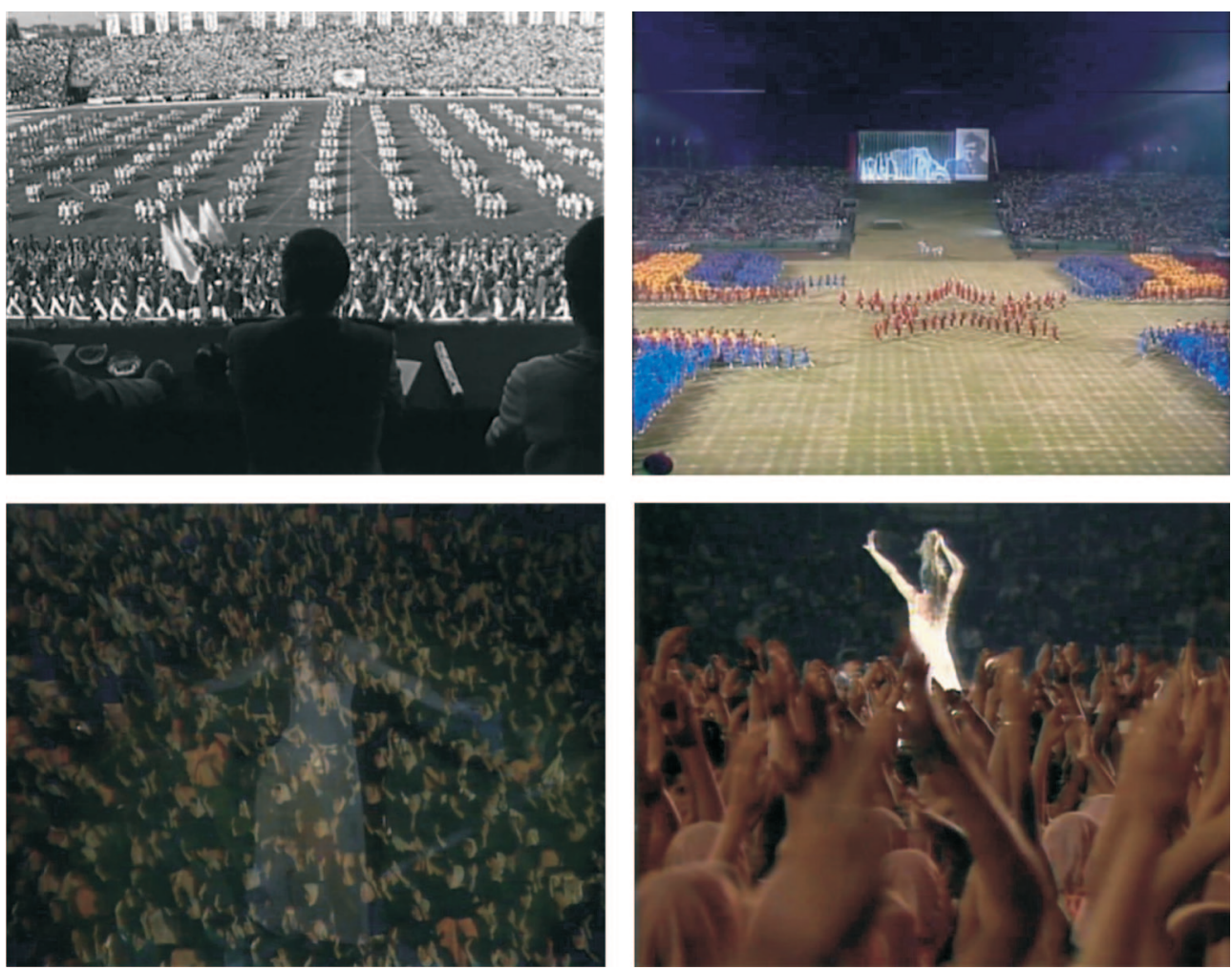

Figures 9-10. Enlargement no. 2 and 4 at the end of Hear my Cry, where the director blows up and freezes the 7 seconds long image four times.
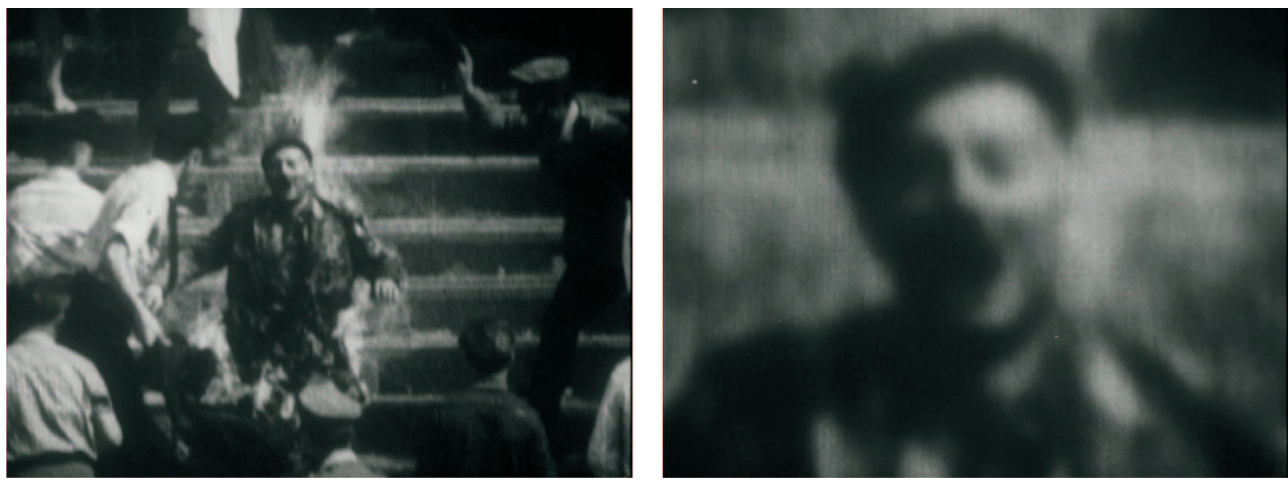
Figures 11-12. Electronic disturbances veiling the images in the digitized version of the VHS tapes in Flotel Europa. .
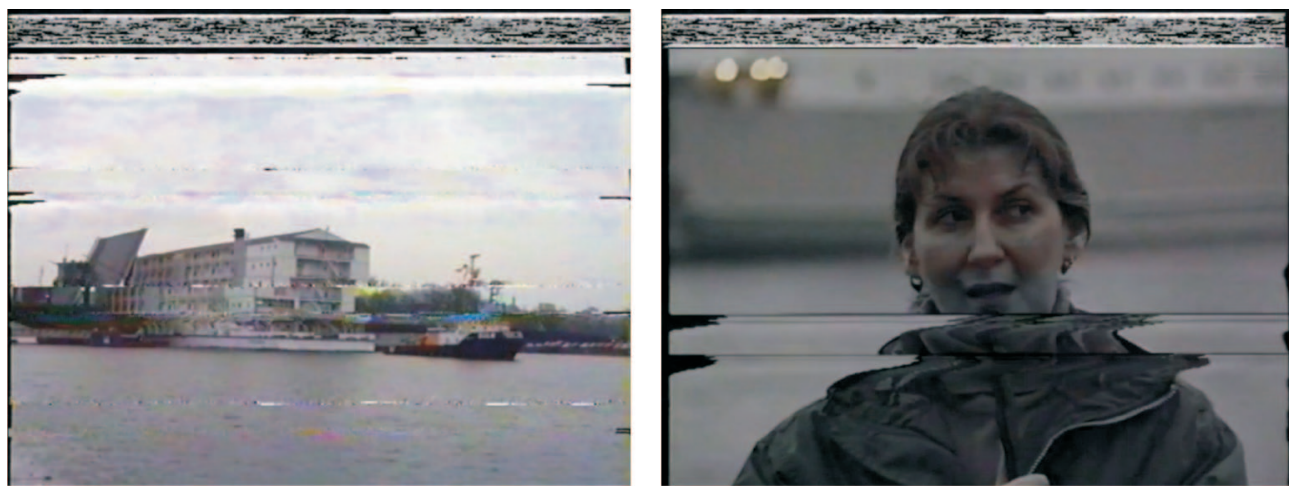

Figures 13-14. The revolution as a disturbance in the live television broadcast in Videograms.
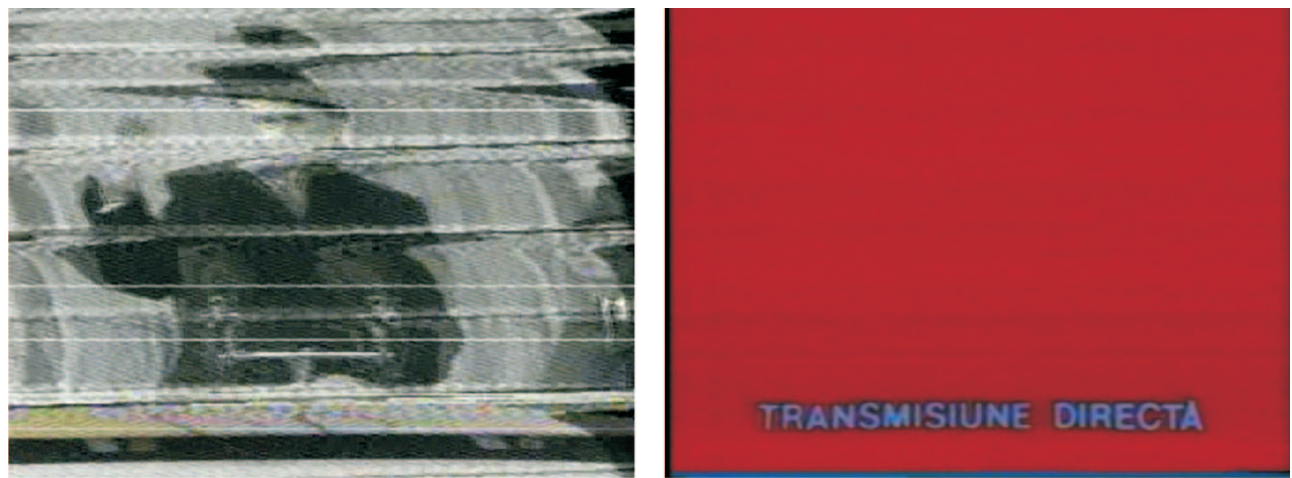

Figures 15-16. The first "free" TV broadcast is being recorded on home video. One of the last images of Elena and Nicolae Ceauşescu shortly before their execution also contains visual imperfection signalling rupture.
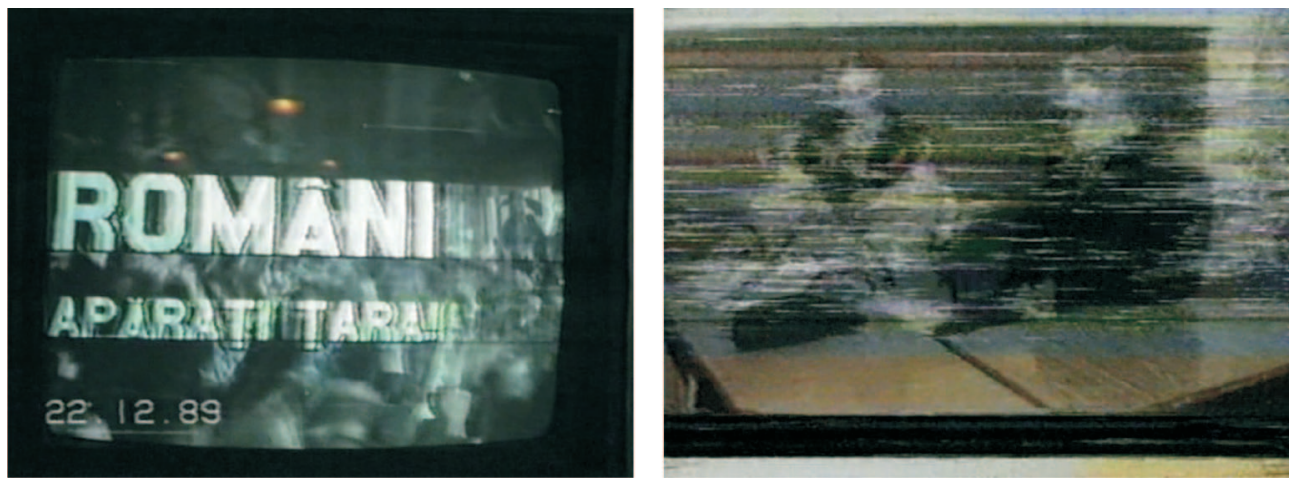
Figures 17-18. In Yugoslavia, the revolts of the 1990s leading to the falling apart of the confederation is interpreted through VHS images of street events, where profilmic smoke also reduces visibility, besides video texture and electronic disturbances.
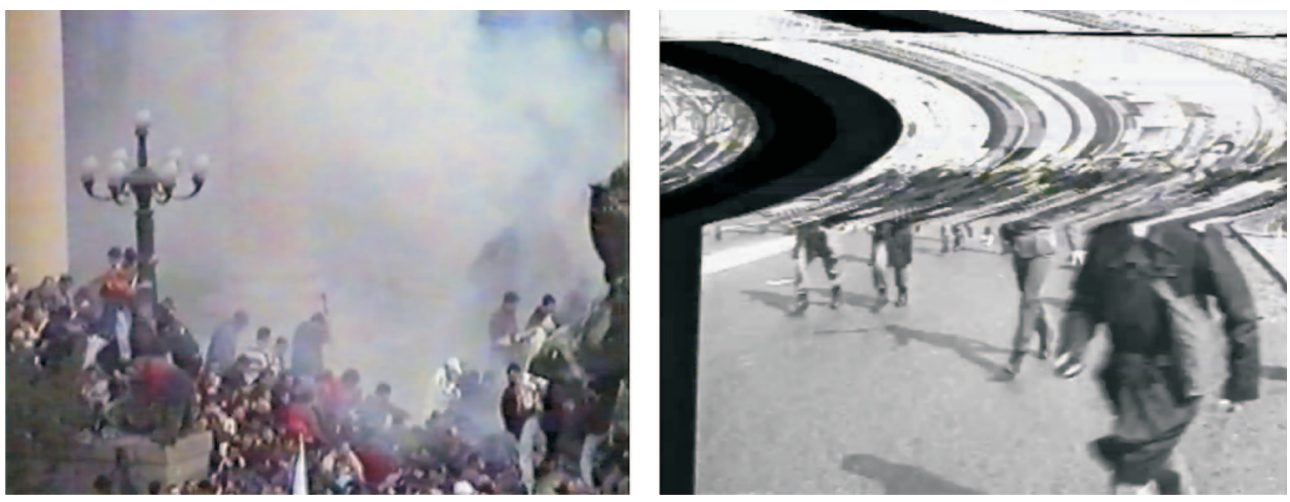

Figures 19-20. The reduction of visibility in The Second Game sometimes results in poetic images reminiscent of the soft focus pictorialist aesthetics. The few close ups and medium shots of the film are actually effacing the players and rendering them uncanny.
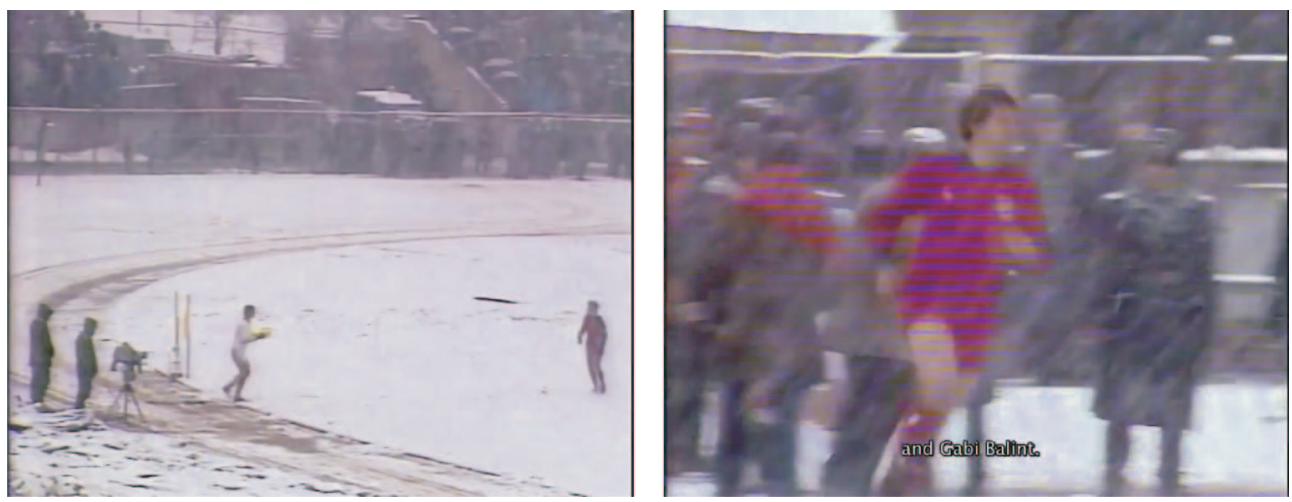


\section{SPECIAL DOSSIER: AN ARCHAEOLOGY OF INTERMEDIALITY STUDIES}

